\title{
Study of External Measurements of Heart in Adult Bangladeshi Population
}

\author{
LUBNA SHIRIN ${ }^{1}$, HUMAIRA NAUSHABA ${ }^{2}$, MOHAMMAD SHAHJAHAN KABIR ${ }^{3}$, SM NIAZUR RAHMAN ${ }^{4}$, \\ TAHMIDAYASMIN ${ }^{5}$, TANBIRAALAM ${ }^{6}$, MD. FARUQUE ${ }^{7}$
}

${ }^{1}$ Lecturer of Anatomy, faculty of Medicine. AIMST University. ${ }^{2}$ Head and Professor, Department of Anatomy, Sir Salimullah Medical College, Dhaka, Bangladesh. ${ }^{3}$ Lecturer of Medicine Unit, Faculty of Medicine AMIST University Kedah, Malaysia.

${ }^{4}$ Tutor of Anatomy, Royal College of Medicine Perak, Malaysia. ${ }^{5}$ Lecturer of Anatomy, Royal College of Medicine Perak, Malaysia. ${ }^{6}$ Lecturer of Physiology, Faculty of Medicine, AIMST University, Kedah, Malaysia. ${ }^{7}$ Professor of cardiology, National Institute of Cardiovascular Disease \& Hospital, Dhaka, Bangladesh.

Address of Correspondence: Shirin L, Lecturer of Anatomy, faculty of Medicine. AIMST University. Ph : +60164069508. Email Address : lubnashirin2012@gmail.com

\begin{abstract}
:
The knowledge regarding normal physical measurement of heart is very important for proper diagnosis and management of various cardiac diseases. Heart disease is a predominant cause of disability and death among all industrialized nations. This study is to establish a standard data of different external parameters of heart of adult Bangladeshi population. The study was conducted at Department of Anatomy, Sir Salimullah Medical College, Dhaka from July 2009 to December 2009. The formalin fixed cadaveric 60 (sixty) (n=60) human hearts, 41 (forty one) male and 19 (nineteen) female were taken. The length, breadth and weight of the heart were measured and the data was analyzed statistically. The mean value of the length of the heart in male was $10.35 \pm 0.62 \mathrm{~cm}$ and female was $10.22 \pm 0.90 \mathrm{~cm}$. The mean value of the breadth of the heart was $7.45 \pm 0.73 \mathrm{~cm}$ and $7.35 \pm 0.65 \mathrm{~cm}$ in male and female respectively. The mean value of the weight of the heart was $174.15 \pm 15.49$ $\mathrm{gm}$ in male, where as for female the mean was $171.58 \pm 19.16 \mathrm{gm}$. The comparison of values of above mentioned variables between male and female were done by unpaired students test and it was statistically not significant.
\end{abstract}

Key words: Cadeveric, External parameter, Bangladesh, Anatomy.

\section{Introduction}

The heart is a hollow, fibro vascular organ. The shape is pyramidal with an apex, base, surface and borders ${ }^{1}$. Structure of the heart in various groups of people varies which is important for the cardiologist and the cardiac surgeon ${ }^{2}$. Cardiovascular diseases are the major causes of morbidity and mortality in the developing countries like Bangladesh. Cardiomegaly represents an enlargement of the heart due either to myocardial hypertrophy, cardiac chamber dilatation and or both. The weight of the heart is affected by sex and body weight and to a lesser extent by body length ${ }^{3-6}$. Long standing uncontrolled hypertension, ischemic heart disease, heart failure, valvular heart disease like aortic regurgitation, mitral regurgitation etc, are the cause of cardiomegaly, which are usually occur in middle and old age group. But interesting finding is that the cardiomegaly in the age group 20-29 can also be manifested in case of early ontest of severe hypertension ${ }^{7}$. So detailed anatomical knowledge is essential for proper diagnosis and treatment of cardiovascular disease. In most of the textbooks the mentioned anatomic variations about the external features of the heart based on the studies of North American or European people. There may be good chance of different geographic variations considering the external parameters of the heart due to variation of gender and body's height and weight 3-6,19. Bangladeshi population might have their own range of physical variations in external measurements of the heart. This present study was done on formalin fixed fresh postmortem hearts of Bangladeshi adult population.

\section{Materials and Methods :}

The present study was carried out on $(n=60)$ human hearts in Bangladeshi people of both sex ageing from 20-70 years. Samples of the heart with surrounding structures were collected from unclaimed dead bodies, within 12-36 hours of death that showed no signs of putrefaction and that are autopsied in the morgues of the department of Forensic medicine of Sir Salimullah Medical College (SSMC) and Dhaka Medical College (DMC). Age of cadavers was collected from the record book of the department of Forensic medicine of DMC and SSMC recorded in the data collection sheet against the respective number of the sample. The cadaver's heart was then kept in 10\% formalin and brought to the department of Anatomy of Sir Salimullah Medical College (SSMC), Dhaka. The study of the external variables of the heart was done on formalin fixed heart as follows. 
The length of the heart was measured from the apex of the heart to a point on the base, just left to the midway between the two right pulmonary veins. The measurement was taken with slide calipers.

The breadth of the heart was measured at the broadest part of transverse diameter of the heart in $\mathrm{cm}$. The measurement was taken by slide calipers.

The weight of the heart was measured in digital electronic balance in gm.

\section{Statistical Analysis :}

All data were recorded systematically in a preformed data collection sheet. Statistical analysis was performed by using Windows SPSS 13.0 version. Unpaired t-test was done to see significance between two groups in relation to sex.

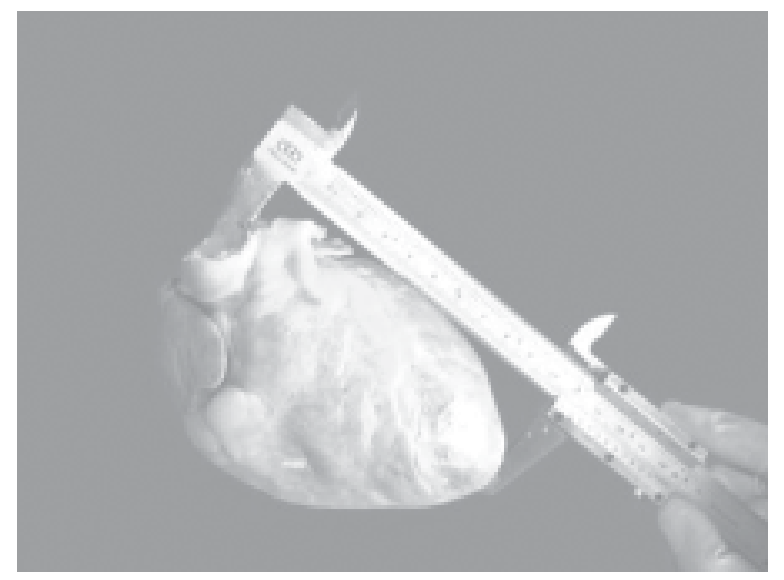

Fig.-1: Photograph of normal adult human heart showing measurement of the length of the heart from apex to base with the help of the slide calipers

\section{Result :}

Table I: Shows the length of the heart in male $(n=41)$ was ranged from 8.40 - $11.20 \mathrm{~cm}$ and mean value was (10.35 \pm 0.62 ) $\mathrm{cm}$ and in female $(\mathrm{n}=19)$ it was ranged from

$8.50-11.50$ and the mean value was $(10.22 \pm 0.90) \mathrm{cm}$. No significant difference $(\mathrm{p}>0.5)$ was found between two groups in terms of the length of the heart. $P$ value reached unpaired t-test. Regarding the breadth of the heart it was ranged from $6.10-8.70 \mathrm{~cm}$ and the mean value was $(7.45 \pm 0.73) \mathrm{cm}$ and $(7.35 \pm 0.65) \mathrm{cm}$ in male and female respectively. The difference in the breadth between two sexes were statistically insignificant $(p>0.5)$ in unpaired $t$ - test.

The weight of the heart was ranged from 130.00-196.66 gm and the means value was $(174.15 \pm 15.49) \mathrm{gm}$ in male, whereas for female group it was ranged 121.40-200.00 gm and the mean value was (171.58 \pm 19.16$) \mathrm{gm}$. The difference between two groups was statistically insignificant ( $p>0.5$ ). the data was analyzed using unpaired t-test.

\section{Table-I}

Length, breadth and weight of the heart in both groups

\begin{tabular}{lcccc}
\hline Groups & $\mathrm{N}$ & $\begin{array}{c}\text { Length } \\
(\mathrm{cm}) \\
\text { Mean } \pm \text { SD }\end{array}$ & $\begin{array}{c}\text { SD Breadth } \\
(\mathrm{cm}) \\
\text { Mean } \pm \text { SD }\end{array}$ & $\begin{array}{c}\text { Weight } \\
(\mathrm{gm}) \\
\text { Mean } \pm \text { SD }\end{array}$ \\
\hline Male & 41 & $10.35 \pm 0.62$ & $7.45 \pm 0.73$ & $174.15 \pm 15.49$ \\
Female & 19 & $10.22 \pm 0.90$ & $5 \pm 0.65$ & $171.58 \pm 19.16$ \\
P value & & $>0.50 \mathrm{~ns}$ & $>0.50 \mathrm{~ns}$ & $>0.50 \mathrm{~ns}$ \\
\hline
\end{tabular}

\section{Discussions:}

In the present study the mean length of the heart was $(10.35 \pm 0.62) \mathrm{cm}$ and $(10.22 \pm 0.90) \mathrm{cm}$ in male female respectively. It was nearly and consistent with studies conducted by Basir (1988) and Rahman (1989) and Begum (1996) in Bangladesh but differ greatly from the studies conducted by Hamilton (1978), Carpentier (1979), Carola etal., (1990), Fawcett (1994), Anderson (2005) in abroad, where they found the mean length of the heart $12 \mathrm{~cm}$. This may be due to ethnic differences among the study populations. In 1996, Sarker found $11.5 \pm 0.59 \mathrm{~cm}$ as the mean length of the heart. Kibria (1999) in his studies conducted that the length of the heart was $(11.5 \pm 0.59) \mathrm{cm}$ and (11.10 \pm 0.46$) \mathrm{cm}$ respectively. Although he studied it in Bangladesh his results are higher than the present study. These authors had studied on unfixed heart $(n=37)$. The present study was based on formalin fixed heart. Formalin induced slight shrinkage cause influences the length of the heart. In this study, the mean breadth of heart was (7.45 \pm 0.73$) \mathrm{cm}$ in male an $(7.35 \pm 0.65) \mathrm{cm}$ in female. Hamilton (1978), Carpentier (1978), Carola et al (1994), Fawcett (1994), Anderson (2005) and Datta (2003) described the mean breadth of heart 8-9 $\mathrm{cm}$, which is higher than the present study. The authors conducted their studies among the different ethnic groups. The present study was not coinciding with the study ${ }^{15}$ conducted by Kibria (1999). He studied on the fresh heart so the present study showed the lower values than the breadth of heart studied of that author. $^{17}$

The present study revealed that the mean weight of the

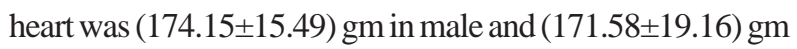
in female respectively. Inconsistent with our findings, Hudson (1965) stated that the weight of the heart was 280$340 \mathrm{gm}$ in male and 230-280 gm in female. According to Gardner and Grey (1969) the weight of the heart was 256$390 \mathrm{gm}$ and 198-279 gm in male and female respectively. 
Hamilton (1978), Carpentier (1979), carola et al (1994), Fawcett (1994) stated that the weight of the heart was 300 gm. Waller BF and Schlant RC (1988) reported that $325 \pm 75$ gm in male and $275 \pm 75 \mathrm{gm}$ in female and female respectively. The findings of the present study were dissimilar with the studies described by those authors. ${ }^{4,} 8-12,18,19$ The variation of the heart in various population of different geographic area depends on their age, sex, body length, epicardial fat and general nutrition. GM Kibria (1999) examined the weight of the heart was $235.95 \mathrm{gm}$. The findings of the present study did not agree with the study ${ }^{17}$ as his study done on unfixed samples.

In the western textbooks and literatures, the mean length described $12 \mathrm{~cm}$, the breadth 8 to $9 \mathrm{~cm}$ and the average weight as $300 \mathrm{gm}$ or more. Almost all the values of length in the present study clustered below $12 \mathrm{~cm}$, similarly those of the weight below $300 \mathrm{gm}$ as well as the majority of the values of the breadth were below $9 \mathrm{~cm}$. Physical values of hearts in western people can be assumed higher in all dimensions because of their higher body surface area and height.

\section{Limitations of the study}

All the viscera were formalin soaked, so shrinkage might be causes the changes in the values if the physical measurements of heart. The viscera were collected from the morgue within 24-48 hours so it is difficult to understand whether the samples were suffering from any cardiac disease or not. Because some cardiac diseases like HTN, heart failure causes crdiomegaly. Proper history of cardiovascular disease should be evaluated from the history sheet. During my study period small amount of female heart was collected and none of the children's heart was collected.

\section{Conclusion:}

This study demonstrated that the external findings of the physical measurement of the heart vary among the different ethnic population due to physical height, weight and body surface area. It also differs between male and female gender. In expanding field of cardiology and cardiac surgery of our country detailed anatomical knowledge regarding physical measurement of heart is important. The present study was designed to contribute for the establishment of Bangladeshi standard data concerning external measurement of heart in details.

\section{References:}

1. RH Anderson, BE Becker. Thorax. In: Williams PL, Standring S, Ellis H, Healy JC, Johonson D, Collins P editors. Gray's
Anatomy. $39^{\text {th }}$ ed. Elsevier Churchill Livingstone; 2005. p. 1001-3.

2. Clinically oriented anatomy. $3^{\text {rd }}$ ed. Baltimore:Lippincott Williams and Wilkins; 1992.p.147.

3. Kitzman DW, Scholz DG, Hagan PT. Age related changes in normal human hearts during first 10 decades of life. Part II (Maturity). A quantitative anatomic study of 765 specimens from subjects 20 to 99 years old. Mayo Clin Proc. 1988;63:137-146.

4. Hudson R. In cardiovascular pathology I. London: Edward Arnold;1965. Structure and function of the heart.

5. Smith HL. The relation of the weight of the heart to the weight of the body and the weight of the heart to age. Am J Heart. 1928;4:79-93.

6. Hangartner JR, Marley NJ, Whitehead A, Thomas AC, Davies MJ. The assessment of cardiac hypertrophy autopsy. Histopathology. 1985;9:1295-1306.

7. $\mathrm{AB}$ Akosa and H Armah. Cardiomegaly in Ghana : An autopsy study. Ghana Med J. Jun 2009;43(2): 93-94.

8. Hamilton WJ editor. Textbook of human anatomy. $2^{\text {nd }}$ ed. London: ELBS. The Macmillan press Ltd; 1978.p.225-45.

9. Carpentier A Guirinon J, Deloche A, Fabiani JN, Relland J. In: Kalmason D, editor. The mitral valve: A pluridisciplinary approach. London: Edward and Arnold; 1979.p.65-77.

10. Carola R, Harley JP, Noback CR. Human anatomy and physiology. New york: McGraw-Hill publishing company: 1990.

11. Fawcett DW. A textbook of histology. $12^{\text {th }}$ ed. Newyork: Champman and Hall; 1994.83.

12. Datta AK. Essentials of human anatomy (thorax and abdomen) $6^{\text {th }}$ ed. Kolkata: Current books International; 2008.p.174-98.

13. Basir KE. Study of patterns and distributions of coronary arteries in adult human postmortem hearts in Bangladesh [thesis]. Dhaka: Univ. of Dhaka; 1988.

14. Rahman ASMH. Anatomy of coronary circulation and dimensions of adult postmortem hearts in Bangladesh [thesis]. Dhaka: Univ. of Dhaka; 1989.

15. Begum J. An Anatomical study of atrio-ventricular valves, muscular part of interventricular septam and papillary muscle of heart among the adult Bangladeshi people [thesis]. Dhaka:Univ.of Dhaka;1996.

16. Sarkar MSA. An anatomical study of coronary arteries and the arch of aorta in adult Bangladeshi people [thesis]. Dhaka: Univ.of ; 1996.

17. Kibria GM. study of the mitral valve in the postmortem heart of adult Bangladeshi males and comparison with stenotic valve. (M.Phil thesis). Dhaka;1999.

18. Gardner E, Gray DY, O’Rahilly R. Antomy: a regional study of human structure $3^{\text {rd }}$ ed. Philadlphia; WB Saunders Company; 1969,p.323-40.

19. waller BF, Schlant RC. Anatomy of heart In: Schlant RC, Alexander RW, O’Rourke R, Robert R, Sonnenblick EH, editor, The heart, $8^{\text {th }}$ ed. New york; McGraw Hill, Inc;1994.p.22-75. 